\title{
Training in Neurology: Identifying and addressing struggling colleagues in the era of physician burnout
}

Rebecca S. Stainman, MD, Ariane Lewis, MD, Aaron Nelson, MD, Sondra Zabar, MD, and Arielle M. Kurzweil, MD

Neurology ${ }^{\circledR}$ 2020;95:796-799. doi:10.1212/WNL.0000000000010601
Correspondence

Dr. Stainman

Rebecca.Stainman@

nyulangone.org

Careers in medicine are rewarding, but fraught with challenges that can contribute to burnout, depression, and substance abuse. Burnout is classically defined as chronic workplace stress that has not been managed successfully, and is measured by the Maslach Burnout Inventory, which addresses (1) emotional exhaustion, (2) feelings of cynicism and detachment (depersonalization), and (3) a sense of low personal accomplishment. ${ }^{1}$ Serial surveys demonstrate that neurologists are more likely than the average physician to experience burnout. ${ }^{1}$ Over half of neurologists and neurology trainees in the United States report at least one dimension of burnout. ${ }^{2,3}$

In 2017, the Accreditation Council for Graduate Medical Education (ACGME) mandated that residency programs address well-being more directly and comprehensively, recognizing that "psychological, emotional, and physical well-being are critical in the development of the competent, caring, and resilient physician." In light of this, neurology training programs have instituted various curricula to combat burnout and promote personal wellness. To our knowledge, there are no data on educating neurology residents about how to identify and address colleagues who are experiencing symptoms of burnout and mental health disorders, which are separate but related entities.

We developed a simulation where first-year neurology residents interact with a struggling colleague, played by a male standardized learner (SL), during an objective structured clinical examination (OSCE).

\section{Methods}

In 2017, our neurology faculty worked with expert medical education simulation faculty at the New York Simulation Center to design a 4-station OSCE on interpersonal communication and professionalism for first-year neurology residents. One encounter focused on the recognition and assistance of a struggling colleague. The SL received training on his character: a depressed resident who felt overwhelmed and isolated at work, resulting in alcohol abuse.

Prior to entering the simulation, residents were told that while leaving clinic late in the afternoon they passed a room where another neurology resident (the SL) was sitting at a computer, and that they should (1) ask their colleague if he needs assistance and (2) address his needs.

The SL started each encounter by saying "I just lost a note I was working on forever. Why am I always the last one here?” He exhibited limited eye contact, was slumped over his desk, and at times covered his face with his hands. The SL discussed his struggle to keep up with the increasing responsibilities in residency. In the middle of the encounter, he mentioned, "Things are so bad because I can't even sleep. Even a few beers at night don't help me sleep." If a resident further inquired about alcohol intake, the SL revealed he drank 2 to 4 beers 5 days a week, and sometimes an additional 1 to 2 vodka tonics right before bed; he could not sleep without drinking alcohol, 
and feared becoming an alcoholic like his father. If a resident screened for depression, the SL endorsed feelings of depression, anhedonia, and a low energy level. The SL denied current suicidal ideation (SI), but endorsed prior SI.

A competent resident was expected to recognize that the SL was struggling with more than simply a lost note, ensure he did not drink before or during work (he did not), recognize the excessive alcohol intake and depressive symptoms, and recommend appropriate resources (i.e., the anonymous psychiatry and counseling services for housestaff or the program director).

The encounter ended when the resident and SL formulated a plan or when 10 minutes had passed. The program director, who observed the clinical encounter through one-way glass, and the SL then provided the resident with 5 minutes of verbal feedback. The SL also completed a case-specific checklist to evaluate each resident's performance, marking tasks/components on a 3-point scale: not done, partly done, or well done.

After completing the 4-station OSCEs, residents had a group debriefing session and were surveyed on how prepared they felt for each scenario, how useful it was, and how they would rate their performance on a Likert scale from 1 (worst) to 5 (best). Institutional review board review of this educational project was waived as a quality assurance project.

\section{Results}

The 4-station OSCEs were completed by 32 junior residents in the New York University-Manhattan adult neurology, child neurology, and neuropsychiatry residency programs and the New York University-Brooklyn adult neurology program in 2017 and 2018. When surveyed immediately after the OSCEs, residents reported they felt moderately prepared for this case (mean Likert score 3.4/5) and thought their performance was average (mean Likert score 3.7/5). However, they thought the station was useful (mean Likert score 4.5/5), and 100\% stated the OSCE should be repeated for future classes.

The aggregate results of the SL checklist are shown in the figure. Most residents exhibited strong relationship development and communication skills, although some tasks were accomplished incompletely: communicated intention to help (63\% done well, $37 \%$ partly done), acknowledged the SL's emotions and feelings (38\% done well, 62\% partly done), elicited the SL's story using appropriate questions (34\% done well, 66\% partly done), was accepting and nonjudgmental (78\% done well, $12 \%$ partly done, $10 \%$ not done), and provided clear information on resources (56\% done well, $41 \%$ partly done, $3 \%$ not done). All residents were felt to be professional (6\% completely, $75 \%$ mostly, 19\% somewhat, $0 \%$ not at all).

The majority of residents missed opportunities to screen for harmful behaviors: $97 \%$ did not review symptoms of depression such as changes in appetite, weight, energy, or feelings of worthlessness; $91 \%$ did not ask if the SL drank alcohol that day; 63\% did not discuss SI; and 59\% did not screen for alcohol use.

The SL checklist in 2018 explicitly asked whether residents referred the SL to resources for depression and substance abuse. While all residents suggested seeking help for depression, only half (53\%) directed the SL to specific resources. Only 7\% discussed seeking help for substance use; $0 \%$ cited specific resources to address substance use.

\section{Discussion}

Burnout, a syndrome resulting from chronic workplace stress, is distinct from mood disorders, yet clinicians who experience burnout are at higher risk for depression, suicide, and risky behaviors. ${ }^{1}$ Furthermore, burnout correlates with increased risk of patient safety incidents, poorer quality of care due to unprofessionalism, reduced patient satisfaction, ${ }^{5}$ and physicians leaving medicine. ${ }^{6}$ Earlier identification of burnout allows for earlier implementation of interventions to counteract burnout and treat related mood disorders. This may ultimately help improve patient outcomes.

There is no standardized, evidence-based approach to preventing, recognizing, and responding to burnout in trainees. JAMA issued a consensus statement in 2003 urging a shift in attitude, to recognize and support peers with depression and suicidality. ${ }^{7}$ Residents are at the front line and routinely assess peers' clinical skills and knowledge. It seems prudent that residents would also assess who may be at risk for complications of burnout. To be clear, we are not advocating that residents treat colleagues; rather we as a community can help take the onus of seeking help off the struggling individual. This approach models our values of supporting one another to become successful physicians and provide the best care for patients.

Simulation is an ideal tool to address wellness in peers because it (1) directly teaches residents through interactive experiences, including direct observation and timely feedback and (2) ensures every resident receives the same information about critical wellness resources (which directly aligns with ACGME requirements). ${ }^{4}$ Simulation is a powerful educational tool ${ }^{8,9}$ and its utility has been shown in other departments regarding similar topics. ${ }^{10}$

When surveyed, our residents overwhelmingly found this OSCE to be a valuable experience. While residents may have strong communication skills and relate well to their colleagues, results from the SL checklist reinforced that they can still miss opportunities to screen for concerning sequela of burnout, such as depression and substance use, and may need additional education on specific resources to address burnout and how to escalate to faculty. The individual and group debriefing sessions helped reinforce these desired behaviors. 
A. Areas where residents performed well

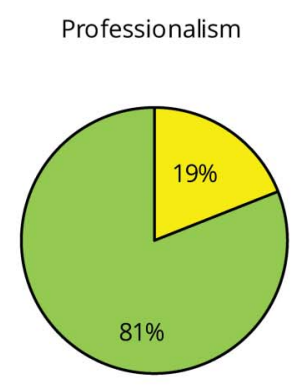

Acknowledged emotions and feelings

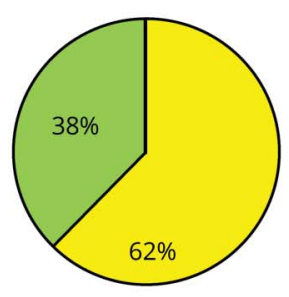

Accepting and nonjudgmental

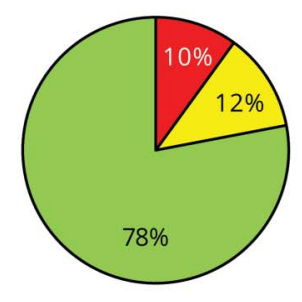

Communicated intention to help

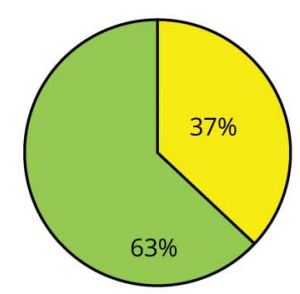

Not done

Partly done

Well done appropriate questions

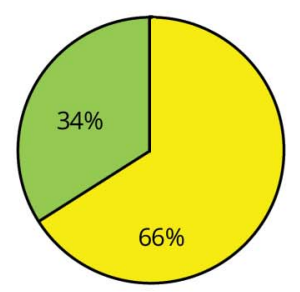

Gave clear information on resources

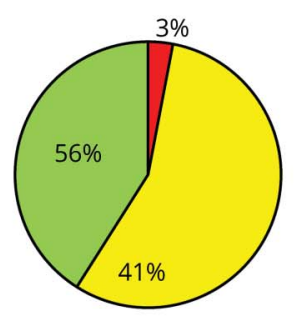

B. Areas where residents rarely screened

Screen depressive symptoms

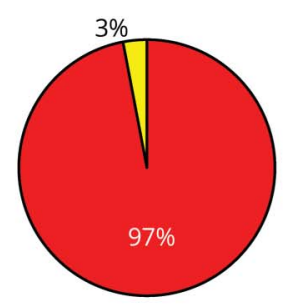

Asked if SL drank today

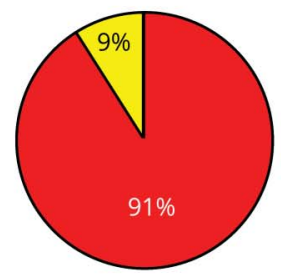

Screen for suicidal ideation

Screen for alcohol use
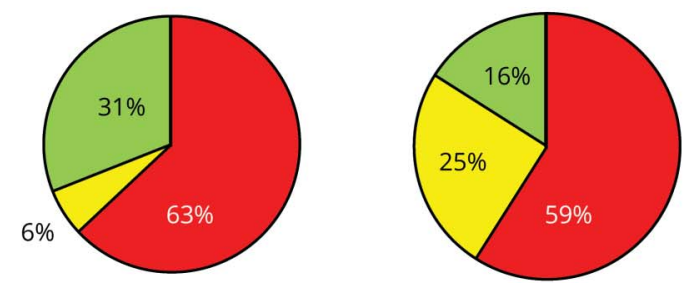

(A) Areas where residents performed well. (B) Areas rarely screened.

We recognize the initiative has some limitations. Some residency programs may not have access to a simulation center or faculty with time to create and run repeated simulations. We do not know the long-term benefits of this simulation. In the future, we hope to survey residents to ask whether they used the information from this simulation to identify and address struggling peers. Anecdotally, since piloting this project, our residents have escalated concerns about colleagues to the program director, specifically citing this simulation as a reminder of what steps to take when in this type of situation.

To our knowledge, this is the first initiative in neurology training to build the critical skills needed to address struggling colleagues. The use of simulation for this topic is also novel. Incorporating this topic as part of our core curriculum emphasizes its value and importance to residents. This curriculum is one step in tackling the challenging issue of burnout that faces the field of medicine.

\section{Acknowledgment}

The authors thank the faculty, standardized learners, and trainees; and The New York Simulation Center for the Health Sciences, a Partnership of The City University of New York and NYU Langone Health, which provided material support of staff, space, and equipment for the educational initiative.

\section{Study funding}

No targeted funding reported.

\section{Disclosure}

The authors report no disclosures relevant to the manuscript. Go to Neurology.org/N for full disclosures. 
Appendix Authors

\begin{tabular}{|c|c|c|}
\hline Name & Location & Contribution \\
\hline $\begin{array}{l}\text { Rebecca S. } \\
\text { Stainman, } \\
\text { MD }\end{array}$ & $\begin{array}{l}\text { Department of Neurology, } \\
\text { New York University School } \\
\text { of Medicine }\end{array}$ & $\begin{array}{l}\text { Analyzed the data, } \\
\text { interpreted the data, } \\
\text { drafted the manuscript for } \\
\text { intellectual content }\end{array}$ \\
\hline $\begin{array}{l}\text { Ariane } \\
\text { Lewis, MD }\end{array}$ & $\begin{array}{l}\text { Departments of Neurology } \\
\text { and Neurosurgery, New } \\
\text { York University School of } \\
\text { Medicine }\end{array}$ & $\begin{array}{l}\text { Interpreted the data, } \\
\text { revised the manuscript for } \\
\text { intellectual content }\end{array}$ \\
\hline $\begin{array}{l}\text { Aaron } \\
\text { Nelson, } \\
\text { MD }\end{array}$ & $\begin{array}{l}\text { Department of Neurology, } \\
\text { New York University School } \\
\text { of Medicine }\end{array}$ & $\begin{array}{l}\text { Revised the manuscript for } \\
\text { intellectual content }\end{array}$ \\
\hline $\begin{array}{l}\text { Sondra } \\
\text { Zabar, MD }\end{array}$ & $\begin{array}{l}\text { Department of Medicine, } \\
\text { New York University School } \\
\text { of Medicine }\end{array}$ & $\begin{array}{l}\text { Designed and } \\
\text { conceptualized study, } \\
\text { revised the manuscript for } \\
\text { intellectual content }\end{array}$ \\
\hline $\begin{array}{l}\text { Arielle M. } \\
\text { Kurzweil, } \\
\text { MD }\end{array}$ & $\begin{array}{l}\text { Department of Neurology, } \\
\text { New York University School } \\
\text { of Medicine }\end{array}$ & $\begin{array}{l}\text { Major role in the acquisition } \\
\text { of data, designed and } \\
\text { conceptualized study, } \\
\text { interpreted the data, } \\
\text { revised the manuscript for } \\
\text { intellectual content }\end{array}$ \\
\hline
\end{tabular}

\section{References}

1. Shanafelt TD, Boone S, Tan L, et al. Burnout and satisfaction with work-life balance among US physicians relative to the general US population. Arch Intern Med 2012; 172:1377-1385.

2. Lafaver K, Miyasaki JM, Keran CM, et al. Age and sex differences in burnout, career satisfaction, and well-being in us neurologists. Neurology 2018;91: E1928-E1941.

3. Levin $\mathrm{KH}$, Shanafelt TD, Keran CM, et al. Burnout, career satisfaction, and wellbeing among US neurology residents and fellows in 2016. Neurology 2017;89: 492-501.

4. Accreditation Council for Graduate Medical Education. ACGME Common Program Requirements. 2017. Available at: acgme.org/Portals/0/PFAssets/ProgramRequirements/CPRs_2017-07-01.pdf. Accessed December 11, 2019.

5. Panagioti M, Geraghty K, Johnson J, et al. Association between physician burnout and patient safety, professionalism, and patient satisfaction: a systematic review and metaanalysis. JAMA Intern Med 2018;178:1317-1330.

6. Sinsky CA, Dyrbye LN, West CP, Satele D, Tutty M, Shanafelt TD. Professional satisfaction and the career plans of US physicians. Mayo Clin Proc 2017;92: $1625-1635$.

7. Center C, Davis M, Detre $\mathrm{T}$, et al. Confronting depression and suicide in physicians: a consensus statement. J Am Med Assoc 2003;289:3161-3166.

8. Mehta T, Strauss S, Beland D, Fortunato G, Staff I, Lee N. Stroke simulation improves acute stroke management: a systems-based practice experience. J Grad Med Educ 2018;10:57-62.

9. Nguyen N, Elliott JO, Watson WD, Dominguez E. Simulation improves nontechnical skills performance of residents during the perioperative and intraoperative phases of surgery. J Surg Educ 2015;72:957-963.

10. Zabar S, Hanley K, Horlick M, et al. "I cannot take this any more!” Preparing interns to identify and help a struggling colleague. J Gen Intern Med 2019;34: 773-777.
ค

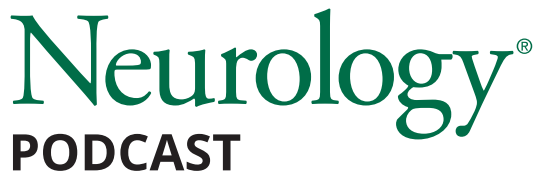

October 27, 2020

\section{The subcortical basis of outcome and cognitive impairment in TBI: A longitudinal cohort study (see p. 774)}

In the first segment, Dr. David Lapides talks with Dr. Martin Monti about his paper on subcortical involvement in traumatic brain injury. Then, Dr. Jeff Burns speaks with Dr. Michael Weiner about his New York Times article on blood tests for Alzheimer disease. Read the NYT article here: https://nyti.ms/3cKheMW.

Disclosures can be found at Neurology.org.

CME Opportunity: Listen to this week's Neurology Podcast and earn 0.5 AMA PRA Category 1 CME Credits ${ }^{\mathrm{TM}}$ by completing the online Podcast quiz. 


\section{Neurology}

\section{Training in Neurology: Identifying and addressing struggling colleagues in the era of physician burnout}

Rebecca S. Stainman, Ariane Lewis, Aaron Nelson, et al. Neurology 2020;95;796-799 Published Online before print August 11, 2020

DOI 10.1212/WNL.0000000000010601

This information is current as of August 11, 2020

\section{Updated Information \&} Services

References

Citations

Subspecialty Collections

Permissions \& Licensing

Reprints including high resolution figures, can be found at: http://n.neurology.org/content/95/17/796.full

This article cites 9 articles, 1 of which you can access for free at: http://n.neurology.org/content/95/17/796.full\#ref-list-1

This article has been cited by 1 HighWire-hosted articles: http://n.neurology.org/content/95/17/796.full\#\#otherarticles

This article, along with others on similar topics, appears in the following collection(s):

\section{Other Education}

http://n.neurology.org/cgi/collection/other_education

Professional conduct and ethics

http://n.neurology.org/cgi/collection/professional_conduct_and_ethics

Information about reproducing this article in parts (figures,tables) or in its entirety can be found online at:

http://www.neurology.org/about/about_the_journal\#permissions

Information about ordering reprints can be found online:

http://n.neurology.org/subscribers/advertise

Neurology ${ }^{\circledR}$ is the official journal of the American Academy of Neurology. Published continuously since 1951, it is now a weekly with 48 issues per year. Copyright () 2020 American Academy of Neurology. All rights reserved. Print ISSN: 0028-3878. Online ISSN: 1526-632X.

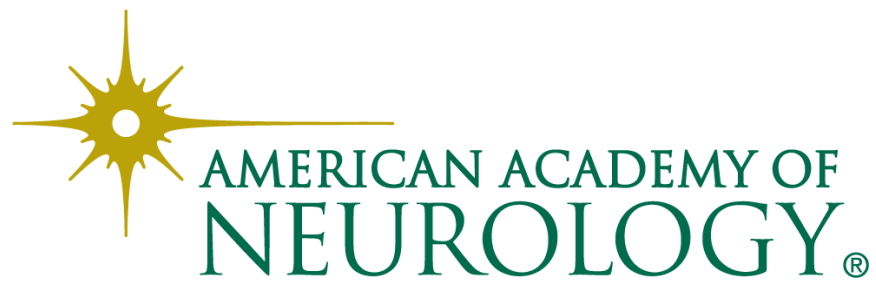

